\title{
La palabra como pincel del desengaño: la écfrasis y el vanitas en tres sonetos del Príncipe del Esquilache
} The word as a brush of disappointment: ekphrasis and vanitas in three sonnets of the Prince of Esquilache

María del Mar Rodríguez Zárate

Universidad de Monterrey, Nuevo León, México

Pontificia Universidad Católica de Chile, Santiago, Chile

Contacto: mdrodriguez3@uc.cl

http://orcid.org/0000-0001-7040-9790

\section{Resumen}

El presente estudio pretende observar cómo la sensibilidad artística del Príncipe de Esquilache recurre a los "trillados" tópicos del Barroco, pero con una anticipada técnica: la écfrasis. Por ello, la relevancia del análisis, a la luz de este aparato poético, muestra una posible lectura capaz de reivindicar la obra de Francisco de Borja y Aragón dentro del marco de la crítica contemporánea. En primera instancia, se rastrearán los conocimientos y la preocupación plástica del príncipe, a la luz de un trabajo ecfrástico tan crítico como literario. Consecuentemente, se destacará la presencia de elementos plásticos del vanitas en sus sonetos LI, LXXIV y XXXVII, cuya construcción lírica muestra la temática barroca del desengaño desde una mirada plástico-lírica. A modo de marco teórico se recurrirá, principalmente, a las menciones de: Del Arco, Zaldívar, Gili Gaya, Vives-Ferrándiz Sánchez, Pimentel, Agudelo Rendón, Riffaterre y Jiménez Belmonte.

Palabras claves: Letras coloniales; Príncipe de Esquilache; Poesía; Écfrasis; Vanitas

\begin{abstract}
The present study pretends to observe how the artistic sensibility of the Prince of Esquilache takes the "well-known" Baroque topics, but under an anticipated technique: the ekphrasis. Therefore, the relevance of the analysis, in light of this poetic apparatus, shows a possible reading capable of vindicating the work of the Francisco de Borja y Aragón within the framework of contemporary criticism. In the first instance, the knowledge and the plastic preoccupation of the prince will be traced, in the light of an écfrastico work as critical as literary. Consequently, the presence of vanitas plastic elements in their sonnets LI, LXXIV and XXXVII will be highlighted, whose lyrical construction shows the baroque thematic of disappointment from a plastic-lyrical perspective. As a theoretical framework will be used, mainly, to the mentions of: Del Arco, Zaldívar, Gili Gaya, Vives-Ferrándiz Sánchez, Pimentel, Agudelo Rendón, Riffaterre and Jiménez Belmonte.
\end{abstract}

Keywords: Colonial letters; Prince of Esquilache; Poetry; Ekphrasis; Vanitas

Recibido: 06.09.19

Aceptado: 26.09.19 


\section{Introducción}

En un palacio valenciano, en medio de lujos, privilegios y riquezas, yacía entre las sombras un hombre, un poeta. Más allá del poder que le brindó su cargo como virrey del Perú, de la fama que gozó entre los intelectuales más destacados de su época, de la abundancia y el exceso de su condición noble, Francisco de Borja y Aragón (1581-1658) fue un hombre "atrapado en el conflicto del ser y el deber ser: ser un poeta y deber ser un funcionario de la corona" (Rondón, 2007, p. 84). Sus múltiples rostros transitan en una lírica espectral, una cuyos silencios y simplicidad logran dar cuenta de un misterioso y complejo entramado de elementos, intenciones y significaciones. Virrey, poeta y hombre aparecen en este enigmático conjunto de sonetos. Composiciones que, como si retuviésemos agua entre las manos, terminan por escabullirse y ocultar sus secretos en la belleza de una obra que no se regodea en elaborados artificios.

No obstante, a pesar de que por muchos años se le posicionó en igual relevancia junto a escritores contemporáneos suyos como Lope de Vega, Gracián, Quevedo y Góngora ${ }^{1}$, su presencia se fue desdibujando de los espacios críticos; incluso en la más reciente revalorización del Barroco, con la llegada del siglo XX. ¿Qué convirtió en fantasma de papel a este virrey-poeta tan notable biográfica y textualmente? Quizás se deba a que la mayor parte de su poesía tiende a caer en temáticas trilladas, a encajonarse en su gran influencia horaciana y a mostrar una mentalidad aristocrática-escéptica, generando

[...] que la crítica del s. XX — contra lo que pensaron los contemporáneos de Esquilache- se desinterese por un poeta que ofrecía pocas novedades en comparación con el afán novedoso a ultranza de los autores que ahora estimamos como más representativos de su tiempo. (Gili Gaya, 1961, p. 257)

No obstante, el presente estudio pretende vislumbrar el rostro de este "fantasma" de las letras coloniales, al mostrar cómo su sensibilidad artística recurre, en efecto, a los "trillados" tópicos del Barroco, pero con una anticipada técnica: la écfrasis. Por ello, la relevancia del análisis, a la luz de este aparato poético, muestra una posible lectura capaz de reivindicar la obra del Príncipe de 
Esquilache dentro del marco de la crítica contemporánea. En primera instancia se rastrearán los conocimientos y la preocupación plástica del príncipe, a la luz de un trabajo ecfrástico tan crítico como literario. Consecuentemente, se destacará la presencia de elementos plásticos del vanitas en sus sonetos LI, LXXIV y XXXVII, cuya construcción lírica muestra la temática barroca del desengaño desde una mirada plástico-lírica. A modo de marco teórico se recurrirá, principalmente, a las menciones de: Del Arco, Zaldívar, Gili Gaya, Vives-Ferrándiz Sánchez, Pimentel, Agudelo Rendón, Riffaterre y Jiménez Belmonte.

\section{Examinador y pintor: la écfrasis crítica y literaria en la obra del Príncipe de Esquilache}

Existe un hilo capaz de entretejer lazos estéticos entre las distintas producciones artísticas: la sensibilidad. Como nudo primario que inicia toda mediación, lo sensible permite que las artes puedan compartir, apropiar y migrar sus formas de una disciplina a otra, para potenciar su expresión, su subjetividad y su capacidad sensitiva. Tal ha sido el caso de la plasticidad y lo poético, saberes que desde la antigua retórica hasta la crítica moderna han estrechado sus fronteras en torno a un lenguaje unísono. De ello dieron cuenta los griegos y romanos, puesto que "según Plutarco, es el poeta Simónides de Ceos en el siglo VI a. C. quien defendió la pintura como 'poesía muda' y la poesía como "pintura que habla"” (Agudelo, 2012, p. 76), enhebrando con ello a la teckné y la rhetorikè al presentarlas como dos operaciones posibles de un mismo artesano-creador. Por consiguiente, tomando como base La Poética de Aristóteles, Horacio desarrollará su Ars Poetica, donde declara que "poeta y pintor son hacedores de imágenes" (Agudelo, 2012, p. 77). Sin embargo, su "ut pictura poesis (como la pintura es la poesía) sentaría las bases de una discusión que se ha mantenido hasta nuestros días" (Agudelo, 2012, p. 76). Delimitación y discusión que Gotthold Ephraim Lessing, escritor alemán ilustrado, asentará como un legado que pronto engendrará un concepto fundamental para la crítica literaria y artística contemporánea: la écfrasis. Como apunta Agudelo, Lessing pretende señalar que:

Horacio no está diciendo que la pintura y la poesía sea una misma y 
la misma cosa, tampoco que exista una radical diferencia entre ésta y aquella; más bien, hay una presentación de dos artes particulares que entran en diálogo según la comparación de Simónides. (2012, p. 77)

Hasta este punto, debemos detener momentáneamente nuestra explicación para así poder introducir un importante detalle biográfico del Príncipe de Esquilache, directamente ligado a la genealogía anterior. Al rastrear su formación intelectual, es posible evidenciar que "Esquilache sabía y traducía el latín clásico, a juzgar por las menciones de Ovidio, Virgilio, Horacio, Séneca, Persio y Marcial" (Del Arco, 1950, p. 34), teniendo, por tanto, un contacto directo con el legado horaciano. No obstante, esta aproximación no se limitará única y exclusivamente a alusiones recurrentes dentro de sus trabajos en prosa y en verso. Gracias a su avanzado manejo de la lengua latina, como bien señala María Inés Zaldívar citando a Gili Gaya, tuvo una "sólida educación letrada, de vertiente horaciana, pues «compuso una traducción de la Oda V del libro II, Nondum subacta, que Menéndez Pelayo, tan conocedor del poeta romano y exigente con sus traducciones, no vacila en calificar de 'buena'»" (2016, p. 17); este ejercicio y formación marcarían fuertemente el estilo lírico y prosaico de su producción. Por ello, como destaca Gili Gaya, al conocer la obra del Príncipe de Esquilache:

[...] el lector revive la influencia constante del Horacio de las Odas, y más aún de las Epístolas doctrinales y de las Sátiras apacibles. En el prólogo al poema heroico Nápoles recuperada, hace Esquilache profesión de fe horaciana; y los censores de la edición alaban el perfecto ajuste del poema a los preceptos clásicos que para la épica dio la Epistola ad Pisones. (1961, pp. 259-260)

He ahí el porqué hemos debido establecer la genealogía anterior. La formación del Príncipe hace posible evidenciar el rol trascendental que tiene para la crítica de la época los preceptos estéticos horacianos, así como el dominio preponderante del propio Esquilache en torno a ellos. Su concepción lírica y estética, por tanto, se inscribe en la tradición del ut pictura poesis; precepto que, como mencionábamos, comprende la tarea poética como un lienzo en blanco, donde las palabras pintan, cual óleo, un lenguaje recatado pero poderosamente sensitivo. Ello se muestra en la carta IX de su compilación Obras (1654), dirigida al sexto duque de Alba, Fernando Álvarez de Toledo, donde Esquilache "hace 
una defensa clásica del decoro horaciano: 'Pues unos que se precian de pintores / y ponen sin discurso ni recelo, / y de ellos dijo Horacio que pintaban / en las olas ciprés, nave en el suelo (239)" (Jiménez, 2007, p. 211). Así, Esquilache se separa tajantemente del alabado culteranismo de su época, instalándose dentro de una tradición estética que, hasta nuestros días, suscita innumerables discusiones y reelaboraciones teóricas. ¿Puede, en este sentido, ser el poeta un pintor sin mutar hacia una tarea ajena del ámbito lírico?

Volvemos, de partida, a nuestra genealogía. Aunque como citáramos arriba Lessing intenta "aclarar" la intención horaciana, generando una distinción entre el quehacer poético y pictórico, autores como W. J. T. Mitchell y Michel Riffaterre continuarán la discusión suscitada por el ut pictura poesis. No obstante, nos centraremos únicamente en las nociones establecidas por Riffaterre, puesto que son de mayor pertinencia a nuestro análisis.

Dentro de las muchas definiciones de la écfrasis, para Riffaterre es claro que se trata de un procedimiento doblemente mimético, donde se "representa con palabras una representación plástica” (2008, p. 161). Por tanto, como también concuerda Zaldívar, "este recurso realizado con fines estéticos pretende recrear y representar, por medio del lenguaje y sobre la hoja de papel, un objeto del arte plástico" (1998, p. 19). Así, en la suma de recursos visuales y retóricos, la écfrasis se manifiesta como una expresión sensible que da cuenta del deseo del arte por aniquilar las barreras del signo. Por ello, al haber una migración del mundo visual al mundo lírico, es claro que, como característica elemental, ésta guarda "una relación intersemiótica, $\mathrm{y}$, puesto que el texto verbal asume la representación del objeto plástico, al que lee como si fuera un texto, la relación también se plantea como intertextual" (Pimentel, 2003, p. 288). Sin embargo, esta conexión se establece de doble partida:

[...] no sólo vincula al poema con otro texto que está fuera de él, sino que la vinculación la establece con otro texto que utiliza un sistema de signos diferentes: el color, la línea, la forma, el volumen, que son de otra naturaleza que el lenguaje escrito. (Zaldívar, 1998, p. 20)

Además, es importante señalar que dicha vinculación no tiene por qué 
remitirse estrictamente a un objeto artístico existente y real, puesto que "es ilusoria, ya sea porque su objeto es imaginario, o bien porque su descripción tan solo hace visible una interpretación dictada menos por el objeto real o ficticio que por su función en un contexto literario" (Riffaterre, 2008, p. 161).

En resumidas cuentas, la écfrasis es "una representación verbal de un objeto o imagen reales y concretos, o imaginarios y ficticios, y cuya finalidad es producir una nueva imagen, pero esta vez mental" (Agudelo, 2017, p. 58), generando un signo icónico que el interpretante pueda imaginar desde su propia experiencia sensible. Pero en ello, Riffaterre señala una distinción pertinente entre la écfrasis crítica y la écfrasis literaria.

Por un lado, la écfrasis crítica supone la existencia de un cuadro concreto y real, siendo su tarea principal "formula[r] juicios de valor variados y basados en principios estéticos explícitos: condena o elogia, quiere formar el gusto de sus lectores" (Riffaterre, 2008, p. 162). Es aquí donde hemos de retornar a la figura del Príncipe, puesto que es posible observar en su obra el ejercicio de dicho tropos. Así, en la epístola IV a D. Francisco de Castro, Conde de Lemos, es posible apreciar una "curiosa y nueva [...] comparación del flamante estilo culterano con el 'hórrido bosquejo' del Greco" (Del Arco, 1950, p. 112), donde Esquilache da cuenta, no solo de su erudición en materia pictórico-literaria, sino de su participación activa en la discusión crítica y cultural de su época. De esta forma, mediante este ejercicio ecfrástico-crítico, "nuestro poeta, [considera que] El Greco es oscuro, ininteligible, recóndito, como poesía culterana" (Del Arco, 1950, p. 113); apunte relevante no solo para la recepción de la obra pictórica, sino también como una clara señal del poderoso canal comunicativo que representó la poesía de su tiempo y la estrecha relación que guardaría con el resto de los quehaceres artísticos.

Asimismo, "en el soneto CLXXIV aporta otra comparación, también pictórica - lo que acusa su conocimiento y afición por este arte..." (Del Arco, 1950, p. 119), elaborando una segunda écfrasis crítica sobre la obra pictórica de Gerónimo Bosco. Lo anterior no solo le sirve para validar su posición como 
figura de renombrado gusto estético, sino también para constatar su participación en el mundo letrado de su época, puesto que Góngora ya había emitido algunas opiniones en torno a dicho objeto plástico. Sin embargo, su intervención se da desde el aparato lírico, dando cuenta, nuevamente, del poder de la palabra poética como mediador entre las expresiones artísticas de la época. De esta forma, "la mención del pintor Bosco como enigmático y oscuro, en relación con el culteranismo, cuando escribe: [...] Gerónimo Bosco, si bien pintor excelentísimo e inimitable" (Del Arco, 1950, p. 109) nos muestra la delgada línea que delimita los saberes artísticos y, con ello, la doble relevancia del Príncipe de Esquilache como poeta y esteta, como crítico de arte y como hombre de poder letrado.

En cuanto a la écfrasis literaria, segunda distinción de Riffaterre, el objeto de estudio no se ve restringido a ser una materialidad concreta, puesto que su representación "presupone el cuadro, sea éste real o ficticio" (2008, p. 162). Así, "la écfrasis literaria es la representación verbal de la intención interpretativa de la obra plástica, interpretación realizada por el escritor y que él, con su arte literario, recrea en relato" (Agudelo, 2017, p. 63). Peor, quizás, lo más relevante de esta noción es la búsqueda concreta por generar admiración ${ }^{2}$ en el lector, lo que inmediatamente nos remite, por su raíz etimológica, a un elemento trascendental del mundo visual y lírico: la mirada. Así, desde un sentido literal, como rescata María Moliner, la mirada "viene del latín 'mirari', admirar, que luego derivó en contemplar, mirar” (en Zaldívar, 1998, p. 20, destacado por mí). El acto, en sí mismo, "implica construir visualmente un objeto, para verlo, en primer lugar, dentro del sujeto que mira" (Zaldívar, 1998, p. 20), donde se establece una relación profunda entre quien observa y recrea su experiencia, en búsqueda de un otro que pueda llegar a compartir dicha visión. Por tanto, la écfrasis constituye "un complejo juego entre la visualidad y sus aparatos, donde la visión y la mirada se yuxtaponen a los procesos de decodificación y lectura" (Alberdi, 2016, p. 18).

Pero ¿desde dónde se instala la figura de nuestro virrey poeta en dicha distinción? El Príncipe de Esquilache también participa de este tropos, pero con un objetivo innovador. Tomando el conocido tópico del desengaño (memento 
mori), algunos de sus sonetos generan una écfrasis literaria que pinta, mediante versos, cuadros imaginarios y visiones reminiscentes a un movimiento pictórico trascendental: el vanitas. A continuación, analizaremos en dicha tradición tres sonetos - los números LI, LXXIV y XXXVII—, cuya construcción lírica muestra la temática barroca del desengaño desde una mirada plástico-lírica.

\section{Pintando vanitas con palabras: la mirada lírico-pictórica en torno al desengaño}

El poder visual hace que el quehacer artístico no solo se repliegue únicamente a la conmoción de lo sensitivo. Nuestros ojos adquieren significación cuando la visión mira desde lo físico hacia lo mental. Mediante la écfrasis, palabra, plasticidad y visión materializan un conducto capaz de "trazar líneas conceptuales que indudablemente involucran al espectador desde lo que piensa o puede pensar sobre un tema particular" (Agudelo, 2017, p. 70). Al despertar el sentido más noble, la vista, "se vinculan los conceptos a la conciencia por encima de la información que proporciona el resto de los sentidos" (Vives-Ferrándiz, 2011, p. 34), puesto que nuestra cognición sintetiza su experiencia vital mayoritariamente en imágenes. Lo mirado se hace visible para un otro mediante el producto artístico, transmitiendo, simultáneamente, imágenes con carga simbólica y conceptual. Por ello, esta relación lírico-plástica incita a una acción, tan sensible como sensitiva, capaz de involucrar a todos sus actantes. De ahí que el vínculo lírico-plástico, planteado desde la écfrasis, no "trata solo de la metáfora sino de los efectos conceptuales y reales de esa metáfora, de lo que el arte puede hacer y mover en el mundo" (Agudelo, 2017, p. 70).

El Barroco no fue ajeno a dicho poder trascendental: "el empleo de medios visuales fue un recurso constante y eficaz en la estrategia propagandista que busca la cultura barroca" (Vives-Ferrándiz, 2011, p. 35). Su pintura y poesía estrechan lazos en torno a dos elementos que incesantemente demandan el empleo de la écfrasis y, con ello, la mirada del espectador-lector. El primero es el conocido tópico del desengaño, "temática y actitud existencial que llegó a permear todos los géneros literarios de la temprana edad moderna" (Quintero, 
2018, p. 148), presentando, mediante la contemplación del sentido existencial del hombre, un despertar que nos recuerde nuestra condición efímera. Por su parte, el segundo elemento, el vanitas, "se ha utilizado casi exclusivamente con relación a la pintura" (Quintero, 2018, p. 148), donde su tradición parte de la representación plástica de la muerte mediante el icono de la calavera. No obstante, a pesar de ser un género propio del código visual, el vanitas guarda una carga semántica que se vincula con lo poético: "comunica el mismo mensaje: la vida es efímera y el mundo ilusorio" (Quintero, 2018, p. 148). Por ello, como advertencia contemplativa de la vanidad mundana, el vanitas "es una composición de carácter emblemático con su combinación de imagen-palabra" (García, 2011, p. 13), donde la metáfora del desengaño se transmuta a las formas de lo visual, sin abandonar su sentido lírico.

Así, puesto que "estas dos tradiciones, una literaria y la otra visual, se desarrollaron simultáneamente y llegaron a un auge durante la época del Barroco" (Quintero, 2018, p. 148), es posible observar que el Príncipe de Esquilache elabora una serie de écfrasis literarias que apuntan a la construcción de un vanitas ilusorio, elemento que le permite potenciar la transmisión lírica del tópico del desengaño.

En primera instancia, es evidente que sus sonetos LI, LXXIV y XXXVII generan descripciones detalladas que otorgan plasticidad al espacio, objetos $\mathrm{y}$ figuras que transitan su lírica. Este elemento resulta clave para el ejercicio ecfrástico, puesto que, en su carácter mimético, se necesita de una debida exposición sensitiva para hacer visible la mirada interpretativa de la voz poética. Incluso en los progymnasmata ${ }^{3}$ el vocablo ekphrasis se utilizó “como un sinónimo de 'exposición' o 'descripción', esto es, cualquier descripción vívida que tenga la capacidad de poner el objeto descrito delante de los ojos del receptor, sea esta una descripción de personajes, hechos, circunstancias, lugares, épocas u objetos" (Alberdi, 2016, p. 23). De ahí que, desde sus orígenes, este recurso retórico ha sido indispensable para la traducción del código visual al código poético.

En los tres sonetos, el uso del color y la excesiva adjetivación fungen casi como si fuesen epítetos. Esto logra enfatizar el rico despliegue de imágenes sensoriales que sugiere la materialidad lírica, incitando nuestra imaginación visual. En el soneto LI, es posible notar la conciencia plástica del Príncipe. Cuando 
se describe la imagen cadavérica de Lucinda: "las blancas manos, y las trenzas rizas" (Borja y Aragón, 2004), la coloración adquiere gran peso en la construcción del imaginario visual del poema. Gracias al anterior recurso, el lector puede mirar doblemente la muerte: desde su presencia física, como cuerpo inanimado, hasta en su sentido conceptual y reflexivo. Además, también contamos con el color rojo y azul, que emanan de las potentes imágenes sensitivas que sugieren el fuego y el hielo. El rol que juega dicha coloración es evidenciar, desde lo visual, la penosa reflexión de la voz poética en torno a la afrenta vida-muerte: "queda el fuego de amor ceniza helada" (Borja y Aragón, 2004).

Por su parte, en el soneto LXXIV, es posible observar, de forma más directa, las pinceladas de la voz poética: "en blando lecho de pintadas flores" (Borja y Aragón, 2004, destacado por mí). La plasticidad de sus descripciones nos lleva a visualizar la belleza de un apacible paisaje: con "guirnaldas de colores", un "monte verde" y un "claro río" (Borja y Aragón, 2004). Armonía que pronto se ve manchada por el giro cruel y sorpresivo de la voz poética, cuando sabemos que dicha riqueza es una vanidad de vanidades que efímeras se consumen: "No así mi vida, que a tu engaño llega, / ingrata Filis, y su nombre pierde, / a sólo destruirse encaminada" (Borja y Aragón, 2004). Contraste amargo que el soneto XXXVII lleva más extremosamente, puesto que desdibuja los colores de la aurora, apagando su luz como símil de la pérdida de la juventud: "se mira ocaso el campo de la Aurora, / y aquella luz, que en los primeros dora, / ya muestra sin color los desengaños" (Borja y Aragón, 2004).

No obstante, como hemos podido alcanzar a percibir, esta descripción ecfrástica y, por ello, claramente plástica, no se limita simplemente a exponer imágenes vívidas y sensitivas que llamen a la interpretación visual del lector. Su intención apunta hacia el vanitas, puesto que construye un imaginario visual capaz de hacer visible el paso del tiempo, el decaimiento y lo efímero. Estas composiciones "reproducen un repertorio de imágenes que corresponden a muchos de los tropos que aparecen una y otra vez en la poesía: velas, relojes, y el mismo espejo, entre otros" (Quintero, 2018, p. 153), elementos que, asimismo, estos 
sonetos re-apropiarán con su nota visual. Así, en el soneto LI, ya encontramos un elemento del vanitas en la primera estrofa, circunscribiendo la descripción inicial en torno a un reloj de arena:

Miraba Fabio en un reloj de arena de la muerta Lucinda las cenizas, las blancas manos, y las trenzas rizas, olvido triste, y afrentosa pena. (Borja y Aragón, 2004)

A diferencia de otros poemas y obras pictóricas, la representación simbólica del reloj no solo se remite a exponer la problemática del paso del tiempo. Son las propias cenizas de Lucinda, sus restos y su cuerpo, los que perturban visualmente la contemplación de la voz poética. Con ello, el reloj adquiere una doble significación: por un lado, se manifiesta como consumidor temporal y vital y, por el otro, como espacio de sepultura o urna mortuoria. Muerte y tiempo se fusionan como el óleo en esta imagen, transformando la metáfora en una visión sensible del memento mori, lo efímero y la pérdida. A ello se le suma la imagen de la espada: " $\mathrm{O}$ no excusado golpe de la muerte / Pues corta siempre con la misma espada; / la dulce vida, y la amorosa suerte" (Borja y Aragón, 2004), jinete imperante que transgrede la vida velozmente, rememorando visualmente nuestra fragilidad humana.

En los sonetos LXXIV y XXXVII, el procedimiento ecfrástico inserta la presencia de la calavera en una visión más próxima a la naturaleza muerta. En el poema LXXIV, la voz poética ejerce como un paisajista que nos inserta dentro de la belleza y el desbordado espectáculo estético que suscita la naturaleza ibérica:

De un monte baja un río despeñado, al son de lisonjeros ruiseñores, $\mathrm{y}$ en blando lecho de pintadas flores recibe el huésped fugitivo el prado. Corriendo llega al valle coronado de ramas, y guirnaldas de colores, y en él sus aguas sin crecer mayores, le dejan en el Tajo sepultado. (Borja y Aragón, 2004, destacados por mí) 
No obstante, la muerte se infiltra como ligera pincelada mediante el personaje del "huésped fugitivo" y "el Tajo sepultado" (Borja y Aragón, 2004), mostrando que nuestra inmersión en dicho contexto peligra por su decaimiento y por nuestro paso efímero como seres mortales. Sin embargo, la estocada final, que lo posiciona como vanitas, yace en la última estrofa donde el pintor-poeta expone el verdadero carácter de su artificio:

Si el claro río su caudal entrega

el agua, que nació de un monte verde, dichoso mira el fin de la jornada.

No así mi vida, que a tu engaño llega, ingrata Filis, y su nombre pierde, a sólo destruirse encaminada. (Borja y Aragón, 2004)

Al contemplar "el fin de la jornada", la voz poética experimenta el desengaño y ve acechada su engañosa pretensión de pertenencia y dominio de lo terrenal. Su reflexión, por tanto, lo lleva a reconocer la fragilidad del mundo: todo ha de perecer y destruirse, aunque su belleza sea plasmada en el lienzo o en la poesía.

De forma similar, el soneto XXXVII da cuenta de una voz poética próxima a la muerte. Al contemplar la vida como algo que se desvanece, el enunciante se confronta con la verdad que yace detrás de todo artificio: "Hoy me dice la edad, que son mis años / muchos, y breves los que cumplo ahora" (Borja y Aragón, 2004). De ahí que su desengaño se presente a partir del contraste naturaleza y muerte, contemplando en el paisaje el paso del tiempo y los años perdidos:

Sujeto ya al imperio de los daños se mira ocaso el campo de la Aurora, y aquella luz, que en los primeros dora, ya muestra sin color los desengaños. (Borja y Aragón, 2004)

Así, la voz poética identifica su añoranza con la imagen de una aurora que ha perdido su brillo. Lo anterior, le permite materializar su desengaño y proyectarlo de forma visual, generando un objeto de contemplación reflexiva y sensible. Por tanto, al comparar su vida con esta imagen lírica, el hablante reconoce su descolorida senectud, observando en ello su lento transitar hacia la muerte. 
Otro icono simbólico del vanitas es la figura femenina. Como señala Cristina Quintero, "la asociación de la figura femenina con el tópico de vanitas aparece con cierta frecuencia en la pintura de Italia, Alemania y los Países Bajos" (2018, p. 154). No obstante, lo anterior no solo se da desde su aparición corpórea, también puede ser mediante símbolos y elementos representativos del mundo femenino. En el soneto LI, la figura femenina aparece en los restos de Lucinda, fundidos y vertidos como reloj de arena. La calavera se asoma en esas "blancas manos", color representativo de la palidez que surge a partir de la muerte corpórea e incluso de los huesos humanos. No obstante, más interesante aún es la similitud de las curvas de cristal con las del cuerpo femenino, generando un reflejo que devuelve a la voz poética una reflexión desengañada:

Miró la suya en la desdicha ajena, y dijo: ¿Qué beldad no atemorizas, cenizas que inconstante solemnizas, al ser, que a su inconstancia te condena? (Borja y Aragón, 2004)

De tal manera, este cuerpo femenino contenido en una urna-reloj aparece como un "espejo [que] devuelve la verdad de su condición, que ambos son una calavera" (Vives-Ferrándiz, 2011, p. 103). El desengaño aparece en la confrontación visual con ese inexistente cuerpo femenino, consumido y relegado a las cenizas y al tiempo de lo inanimado.

En el soneto LXXIV, la figura de lo femenino está encarnada en Filis ${ }^{4}$, personaje frecuente en la poesía pastoril. Fundiéndose con el vívido y colorido retrato de lo natural, la voz poética se dirige a su figura para compartir su reflexión:

No así mi vida, que a tu engaño llega, ingrata Filis, y su nombre pierde, a sólo destruirse encaminada. (Borja y Aragón, 2004)

Como en el soneto LI, es mediante la figura femenina que la voz poética puede dar cuenta de su desengaño. Para el enunciante, la belleza del paisaje y de lo femenino son, en realidad, solo apariencias y artificios. Inevitablemente y pese a su hermosura, ambas comparten la condición efímera y mortal de lo humano. Aunque el arte pueda presentarlas como visiones eternas, no dejan de transitar 
hacia el fin de la jornada, siendo consumidas, eventualmente, por la muerte.

En el soneto XXXVII, la figura femenina no se presenta de forma tan evidente como en los dos sonetos anteriores. Sin embargo, tiene una manifestación que se adhiere y se transmite gracias a la plasticidad. En el vanitas, lo femenino también puede revelarse mediante "las imágenes trilladas asociadas con la representación de la belleza femenina en términos de brillantes colores y materiales: luz, sol, aurora, rubí, oro y perlas; pero todas aparecen recontextualizadas y examinadas desde una perspectiva crítica y desengañada" (Quintero, 2018, p. 155). De ahí que el elemento plástico de la aurora, referida con letra mayúscula a modo de nombre propio, sea el único indicio de una posible representación de lo femenino: "se mira ocaso el campo de la Aurora / y aquella luz, que en los primeros dora, / ya muestra sin color los desengaños" (Borja y Aragón, 2004).

De esta forma, lo femenino se funde en los elementos simbólicos y plásticos, incorporando la luz, el color y la materialidad del vanitas al código poético. No obstante, más interesante aún es notar que la voz poética posa su mirada en el objeto femenino. Desde su corporeidad y plasticidad, la mujer detona las reflexiones del hablante lírico en torno a la engañosa condición humana. Así, su desengaño nace al contemplar la descolorida aurora: "triste del hombre, que los años llora, / si con ellos no llora sus engaños" (Borja y Aragón, 2004); al mirar en las cenizas de la amada su propia condición: "Miró la suya en la desdicha ajena" (Borja y Aragón, 2004); y tras contemplar la engañosa belleza que Filis representa: "No así mi vida, que a tu engaño llega, / ingrata Filis" (Borja y Aragón, 2004). Por tanto, "con la proximidad de la muerte se va ganando un desengaño que permite mirar al mundo correctamente" (Vives-Ferrándiz, 2011, p. 42), conclusión a la que llega la voz poética mediante la contemplación de figura femenina dibujada en lo poético.

De esta forma, los sonetos del Príncipe de Esquilache pueden ser considerados como écfrasis literarias que generan vanitas líricos, capaces de transmitir visualmente el tópico del desengaño. La mirada juega un papel central en estos poemas. Para llegar al desengaño, la voz poética pinta y contempla en lo 
femenino, natural y en otros elementos simbólicos el artificio de nuestra engañosa condición. Así, mediante vívidas imágenes y descripciones, las figuras y la voz poética interactúan en torno al mirar y el ser mirados. En el soneto LI, Fabio "miró la suya en la desdicha ajena"; en el soneto LXXIV, la voz poética "mira el fin de la jornada"; y, en el soneto XXXVII, "se mira ocaso el campo de la Aurora" (Borja y Aragón, 2004, destacados por mí). De ahí que los sonetos den cuenta de que "la calavera no sólo se mira, se medita o se escucha, sino que también se puede leer" (Vives-Ferrándiz, 2001, p. 60). En tal sentido, estrechando los lazos sensibles del quehacer poético y pictórico, la mirada incita a la acción sensitiva y reflexiva del lector.

\section{Conclusión}

La sensibilidad, como centro de toda expresión artística, acciona nuestro cuerpo y da vida a la metáfora. La écfrasis literaria suscita el encuentro entre la lírica y la plástica, mostrando que "el pintor, el escultor, o el escritor, son todos narradores que cuentan una historia sirviéndose de diferentes medios" (VivesFerrándiz, 2011, p. 66). Su capacidad de relato, al construir imaginarios vívidos, "convierte realmente el arte [...] en un auténtico artefacto cultural, un instrumento con capacidad funcional propia dentro de la cultura" (Vives-Ferrándiz, 2011, p. 66). De ahí que sus envolventes imágenes, descripciones y su búsqueda por la admiración del lector despierten un intercambio activo y sensitivo que habla a nuestra sensibilidad. Lo visual logra ser leído, re-imaginado y re-codificado en la palabra. Por ello, la écfrasis nos invita a contemplar, interpretar y reflexionar en torno al objeto estético.

Los sonetos del Príncipe de Esquilache guardan una misteriosa sencillez que pareciera alejarles de los excesivos decorados y despliegues líricos del Barroco. Su decoro y su apego a la tradición horaciana le han valido el desinterés de la crítica contemporánea, convirtiéndolo en un fantasma de las letras coloniales. El silencio de su legado ha quedado empolvado en el olvido, sin dar cuenta del poder oculto que yace en aquella aparente simplicidad. No obstante, como hemos podido apreciar a lo largo del análisis, este virrey-poeta-hombre — ser de 
múltiples y complejos rostros-, logra construir un imaginario metafórico y visual que se suma a la tradición estética horaciana, pero desde el novedoso tropos de la écfrasis. El Príncipe de Esquilache pinta de forma lírica el conocido tópico del desengaño y su representación visual mediante el vanitas. Con ello, logra aunar ambas tradiciones en torno a una mirada capaz de transmitir al lector-espectador la visión de su condición efímera y mortal. Sus sonetos dan cuenta de que no hay artificio, por más elaborado o simple que se presente, que pueda capturar una imagen vívida, eterna e indestructible de lo vital. Frente a la destrucción que suscita el frío golpe de la muerte, todo resulta una vanidad de vanidades, una apariencia y un engaño que nos traiciona y nos impide enfrentarnos con la naturaleza de nuestra fragilidad. Por ello, desde la écfrasis literaria, los vanitas líricos del Príncipe de Esquilache renuevan la temática del memento mori. Por un lado, consolidan un desengaño que mueve nuestra sensibilidad, y, por el otro, despiertan nuestra mirada y participación sensitiva en torno al despliegue de imágenes simbólicas.

Así, desafiando los límites del signo, su legado sale de las sombras demostrando que el arte es un hacedor misterioso, uno que mueve las fibras de lo sensible y lo sensitivo en torno a la reflexión activa. La metáfora del desengaño no queda encasillada entre las pinceladas o los versos, sino que se imprime en el alma de nuestros cuerpos. Nos invita a contemplarnos desde un reloj de arena, en la aurora, en los valles y ríos como seres de polvo. Al rehabilitar la mirada en torno a este fantasma de las letras coloniales, su rostro espectral nos devuelve en el reflejo de sus écfrasis la visión de nuestra propia calavera. Ojos que hoy leen y miran la belleza del arte, ojos que serán consumidos por las brasas de la muerte y su ceniza helada.

\section{Notas}

1 Como señala Gili Gaya: "Sedano publicó poesías suyas en los tomos $4^{\circ}, 8^{\circ}$ y $9^{\circ}$ de su Parnaso español, incluyéndolo hiperbólicamente entre los nueve grandes líricos de España, al lado de Garcilaso, fray Luis de León, Lope de Vega, los dos Argensola, Quevedo, Rebolledo y Villegas" (1961, p. 255).

2 Como señala Riffaterre: "por el contrario, la écfrasis literaria busca su admiración: al 
ser una variedad del encomio, se convierte de hecho en un blasón de la obra pictórica" (2008, p. 162).

3 Definidos por Alberdi Soto como aquellos "ejercicios preparatorios de oratoria escritos por los rétores griegos entre los siglos I y IV d. C” (2016, p. 23).

4 Como señala el Diccionario Akal de Mitología Universal: "Hija de Sitón, rey de Tracia; sucedió a su padre, hospedó a Demofonte tras un naufragio (según otros a Acamante) y se prendó de él siendo correspondida. Como Demofonte (o Acamante) debía regresar a su patria para reorganizar la vida política de Atenas, prometió a Filis que retornaría el día establecido para la boda. Ya que no llegó ese día, la chica, creyéndose abandonada, se ahorcó presa de la desesperación. Atenea, conmovida por tanto sacrificio, la transformó en almendro. Demofonte (o Acamante) regresó al día siguiente y, al no encontrar a su amada, se abrazó al árbol y lloró desesperado. Desde aquel día las ramas desnudas del almendro se recubrieron de ramilletes de flores blancas además de las hojas" (Mestica, 1998, p. 108).

\section{Referencias bibliográficas}

Agudelo Rendón, P. (2012). Los ojos de la palabra. Construcción del concepto de écfrasis, de la retórica antigua a la crítica literaria. Lingüística y literatura, 60, 75-92. Recuperado de https://aprendeenlinea.udea.edu. co/revistas/index.php/lyl/article/view/12548/11341

Agudelo Rendón, P. (2017). Las palabras de la imagen: écfrasis e interpretación en el arte y la literatura. Medellín: Instituto Tecnológico Metropolitano.

Alberdi Soto, B. (2016). Escribir la imagen: la literatura a través de la écfrasis. Literatura y lingüistica. 33, 17-38. doi: 10.4067/S071658112016000100002

Borja y Aragón, F. (2004). Sonetos [1648] de Francisco de Borja, Príncipe de Esquilache; edición de Ramón García González. Alicante: Biblioteca Virtual Miguel de Cervantes. Recuperado de http://www.cervantesvirtual. com/nd/ark:/59851/bmcpr846

Del Arco, R. (1950). El príncipe de Esquilache poeta anticulterano. Zaragoza: Instituto Fernando el Católico (CSIC).

García Mahíques, R. (2011). Prólogo. En L. Vives-Ferrándiz Sánchez, Vanitas: Retórica visual de la mirada (pp. 13-20). Madrid: Encuentro.

Gili Gaya, S. (1961). La obra poética del Príncipe de Esquilache. Nueva Revista de 
Filología Hispánica, 15(1-2), 255-261. doi: 10.24201/nrfh.v15i1/2.418

Jiménez Belmonte, J. (2007). Las obras en verso del príncipe de Esquilache: amateurismo y conciencia literaria. Nueva York: Tamesis Books.

Mestica, G. S. (1998). Diccionario Akal de mitología universal. Madrid: Ediciones Akal.

Pimentel, L. A. (2003). Écfrasis y lecturas iconotextuales. Poligrafias. Revista de Literatura Comparada, 4, 205-215. Recuperado de: http://www.revistas. unam.mx/index.php/poligrafias/article/view/31343.

Quintero, M. C. (2018). Mirada, vanitas y desengaño en la representación de la mujer en tres sonetos de Quevedo. Versants, 65(3), 147-161. doi: 10.22015/V.RSLR/65.3.9

Riffaterre, M. (2008). La ilusión de ecfrasis. En A. Monegal, et ál., Literatura y pintura (pp. 161-183). Madrid: Arco-Libros.

Rondón, V. (2007). Pajarillo que al alba. Cancionero musical del Príncipe del Esquilache. Dirección Sergio Candia. Estudio MusicAntigua. Resonancias, 11(21), 83-86. Recuperado de: http://resonancias.uc.cl/ images/PDF_Anteriores/Separatas_n21/Rondón.pdf.

Vives-Ferrándiz Sánchez, L. (2011). Vanitas: Retórica visual de la mirada. Madrid: Encuentro.

Zaldívar, M. I. (1998). La mirada erótica: Gonzalo Millán/Ana Rossetti. Santiago: RIL Editores -Café Central Barcelona.

Zaldívar, M. I. (2016). Francisco de Borja y Aragón, príncipe de Esquilache. Relación y sentencia del Virrey del Perú (1615-1621). Nueva York: IDEA/IGAS. Recuperado de: http://hdl.handle.net/11354/1676 